\title{
Synthesis of PF-06751979
}

\section{Key words}

\section{PF-06751979}

BACE1 inhibitors

intramolecular

dipolar

cycloaddition<smiles>C=CC[C@H](C)OC/C=N\O</smiles>

$\mathrm{NaOCl}(6 \%, 90 \mathrm{~mL})$

$\mathrm{CH}_{2} \mathrm{Cl}_{2}$ r.t $67 \%$ (60 mmol scale)

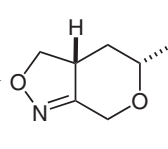

B

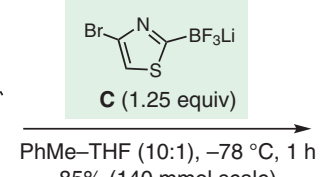
$85 \%$ (140 mmol scale)
A<smiles>COc1ccccc1-c1ccccc1</smiles><smiles>CC1CC(CO)(C(=S)NC(=O)c2ccccc2)CC1(O)NC(=O)c1ccccc1</smiles><smiles>Brc1csc(C23CCONC2CCOC3)n1</smiles>

$\mathrm{Mo}(\mathrm{CO})_{6}(0.5$ equiv

add $\mathrm{NaBH}_{4}$ (4.0 equiv)

$0{ }^{\circ} \mathrm{C}, 1 \mathrm{~h}$ $95 \%(49.5 \mathrm{mmol}$ scale $)$

D
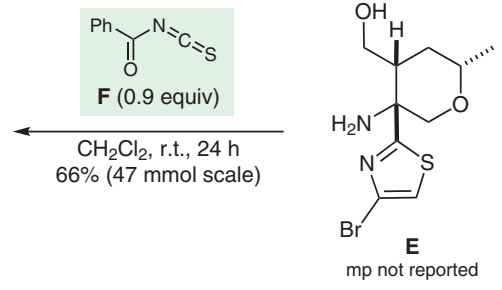

mp not reported

\section{nitrones}

quaternary

stereocenters

Buchwald-Hartwig amination

$\mathrm{MsOH}$ (12 equiv)

$\overrightarrow{\mathrm{CH}_{2} \mathrm{Cl}_{2}, 21^{\circ} \mathrm{C}, 25 \mathrm{~min}}$ $70 \%$ from I<smiles>C[C@@H]1C[C@H]2CSC(NC(=O)c3ccccc3)=N[C@@]2(c2nc(N)cs2)CO1</smiles>

\section{Significance: PF-06751979 is a potent brain} penetrant $\beta$-site amyloid precursor protein cleaving enzyme 1 (BACE1) inhibitor that is of interest for the treatment of Alzheimer's disease. It displays broad selectivity over related aspartyl proteases including BACE2 and cathepsin D. A potential liability of BACE2 inhibition is depigmentation.
Comment: In the key step, the chiral quaternary center in $\mathbf{D}$ was constructed via diastereoselective addition of the metallated thiazole $\mathbf{C}$ to the convex face of the bicyclic isoxazoline $\mathbf{B}$. The direct conversion of bromothiazole I to $\mathbf{N}(61 \%, 0.11 \mathrm{mmol}$ scale) via a Buchwald-Hartwig coupling with 5(difluoromethoxy)picolinamide is also reported. See also the synthesis of LY2886721: Org. Process Res. Dev. 2015, 19, 1214.

SYNFACTS Contributors: Philip Kocienski

Synfacts 2018, 14(08), 0775 Published online: 18.07.2018 Dol: 10.1055/s-0037-1609873; Reg-No.: K03518SF 